\title{
Spectroelectrochemistry and Electrochemistry of Europium Ions in Alkali Chloride Melts
}

\author{
Akihiro Uehara $^{\mathrm{a}}$, Osamu Shirai ${ }^{\mathrm{b}}$, Takayuki Nagai ${ }^{\mathrm{c}}$, Toshiyuki Fujii ${ }^{\mathrm{a}}$, and Hajimu Yamana ${ }^{\mathrm{a}}$ \\ ${ }^{a}$ Division of Nuclear Engineering Science, Research Reactor Institute, Kyoto University, \\ Asashironishi, Kumatori-cho, Osaka, 590-0494, Japan \\ b Divison of Applied Life Science, Graduate School of Agriculture, Kyoto University, \\ Kitashirakawa Oiwake-cho, Sakyo-ku, Kyoto, 606-8502, Japan \\ c Nuclear Fuel Cycle Engineering Laboratories, Japan Atomic Energy Agency, Muramatsu, \\ Tokai-mura, Naka-gun, Ibaraki, 319-1194, Japan \\ Reprint requests to Prof. A. U.; E-mail: auehara@HL.rri.kyoto-u.ac.jp \\ Z. Naturforsch. 62a, 191 - 196 (2007); received December 4, 2006
}

Presented at the EUCHEM Conference on Molten Salts and Ionic Liquids, Hammamet, Tunisia, September 16-22, 2006.

In order to investigate the redox equilibrium of europium ions in molten $\mathrm{NaCl}-2 \mathrm{CsCl}, \mathrm{UV}-\mathrm{Vis}$ absorption spectrophotometry measurements were performed for $\mathrm{Eu}^{2+}$ and $\mathrm{Eu}^{3+}$ in molten NaCl$2 \mathrm{CsCl}$ at $923 \mathrm{~K}$ under simultaneous electrolytic control of their ratio. Molar absorptivities of $\mathrm{EuCl}_{3}$ and $\mathrm{EuCl}_{2}$ in $\mathrm{NaCl}-2 \mathrm{CsCl}$ at $923 \mathrm{~K}$ were determined to be $(420 \pm 21) \mathrm{M}^{-1} \mathrm{~cm}^{-1}$ at $31200 \mathrm{~cm}^{-1}$ and $(1130 \pm 56) \mathrm{M}^{-1} \mathrm{~cm}^{-1}$ at $30300 \mathrm{~cm}^{-1}$, respectively. The formal redox potential of the $\mathrm{Eu}^{2+} / \mathrm{Eu}^{3+}$ couple in $\mathrm{NaCl}-2 \mathrm{CsCl}$ melt at $923 \mathrm{~K}$ was determined to be $(-0.941 \pm 0.004) \mathrm{V}$ vs. $\mathrm{Cl}_{2} / \mathrm{Cl}^{-}$by electromotive force measurements on varying concentration ratios of $\mathrm{Eu}^{2+}$ and $\mathrm{Eu}^{3+}$, which were performed using a technique based on the combination of electrolysis and spectrophotometry. Cyclic voltammetry was also carried out in order to examine the characteristics of the voltammograms for the $\mathrm{Eu}^{2+} / \mathrm{Eu}^{3+}$ couple in $\mathrm{NaCl}-2 \mathrm{CsCl}$ melt. The formal redox potential of the $\mathrm{Eu}^{2+} / \mathrm{Eu}^{3+}$ couple determined by a spectroelectrochemical method agreed with that determined by cyclic voltammetry $\left[(-0.946 \pm 0.008) \mathrm{V}\right.$ vs. $\left.\mathrm{Cl}_{2} / \mathrm{Cl}^{-}\right]$. The effects of temperature on the redox potential of the $\mathrm{Eu}^{2+} / \mathrm{Eu}^{3+}$ couple in $\mathrm{NaCl}-2 \mathrm{CsCl}, \mathrm{NaCl}-\mathrm{KCl}, \mathrm{LiCl}-\mathrm{KCl}$, and $\mathrm{CsCl}$ melts were studied by cyclic voltammetry in the range from 923 to $1123 \mathrm{~K}$.

Key words: Molten Salt; NaCl-2CsCl; Europium; Spectroelectrochemistry; Cyclic Voltammetry.

\section{Introduction}

Recently the development of pyro-reprocessing of spent nuclear fuels, using the oxide electro-winning method, has progressed notably [1]. It has been reported that in this process the efficiency of the electrolysis is seriously affected by circulation currents caused by some fission products and the materials of construction [2]. Solute elements that have two valence states are likely to cause the so-called circulation current. This current occurs by alterenate reduction and oxidation reactions of elements at the cathode and anode. Europium has divalent and trivalent states that can exist in the electrolysis process and may contribute to the circulation current in the process.

The redox behavior of europium ions in molten alkali chlorides has been investigated [3-8]. Recently, Novoselova et al. [5, 6] have determined the formal re- dox potential of the $\mathrm{Eu}^{2+} / \mathrm{Eu}^{3+}$ couple, $E_{\mathrm{Eu}}^{\mathrm{o}}(\mathrm{II}) / \mathrm{Eu}(\mathrm{III})$ in alkali chloride melts such as $\mathrm{LiCl}, \mathrm{KCl}, \mathrm{CsCl}$, and $\mathrm{NaCl}-\mathrm{KCl}$ by electromotive force measurements. Kuznetsov and co-workers $[7,8]$ have determined the formal redox potentials of $\mathrm{Eu}^{2+} / \mathrm{Eu}^{3+}, \mathrm{Eu}^{3+} / \mathrm{Eu}$ and $\mathrm{Eu}^{2+} / \mathrm{Eu}$ couples in $\mathrm{NaCl}-\mathrm{KCl}, \mathrm{KCl}$ and $\mathrm{CsCl}$ by linear sweep voltammetry. Spectroelectrochemistry [9] is an effective method to determine the formal redox potential precisely. In this method, the electromotive force of the solution, which contains both the oxidant and reductant, is measured. The concentration ratio of $\mathrm{Eu}^{2+}$ and $\mathrm{Eu}^{3+}$ is controlled by electrolysis and monitored by spectrophotometry simultaneously, and $E^{\mathrm{o} \prime}$ can be evaluated based on the Nernst equation. Smirnov [10] and Nagai et al. [11,12] have applied this method to determine the formal redox potential of $\mathrm{Cr}^{2+} / \mathrm{Cr}^{3+}, \mathrm{Ni}^{2+} / \mathrm{Ni}^{3+}, \mathrm{U}^{3+} / \mathrm{U}^{4+}$, and $\mathrm{UO}_{2}{ }^{+} / \mathrm{UO}_{2}{ }^{2+}$ in molten salts. 
In the present study we report the formal redox potential of the $\mathrm{Eu}^{2+} / \mathrm{Eu}^{3+}$ couple for $\mathrm{NaCl}-2 \mathrm{CsCl}$, determined by a spectroelectrochemical method. The $\mathrm{NaCl}-$ $2 \mathrm{CsCl}$ system [1] is considered as a solvent for the oxide-winning method of spent nuclear fuels. However, there is a limited number of absorption spectra of $\mathrm{Eu}^{2+}$ and $\mathrm{Eu}^{3+}$ reported for molten salts [13-16]. To our knowledge, no detailed spectra of $\mathrm{Eu}^{2+}$ and $\mathrm{Eu}^{3+}$ in $\mathrm{NaCl}-2 \mathrm{CsCl}$ molten salt have been reported before. Hence, the absorption spectra of $\mathrm{Eu}^{2+}$ and $\mathrm{Eu}^{3+}$ in a $\mathrm{NaCl}-2 \mathrm{CsCl}$ eutectic melt, which are a fundamental information for spectroelectrochemistry, were precisely measured, and then the formal redox potential of the $\mathrm{Eu}^{2+} / \mathrm{Eu}^{3+}$ couple was determined by a spectroelectrochemical method. The redox potentials of the $\mathrm{Eu}^{2+} / \mathrm{Eu}^{3+}$ couple were also determined by cyclic voltammetry for the systems $\mathrm{NaCl}-2 \mathrm{CsCl}, \mathrm{NaCl}-\mathrm{KCl}$, $\mathrm{LiCl}-\mathrm{KCl}$, and $\mathrm{CsCl}$, and their temperature dependence was carefully investigated.

\section{Experimental}

\subsection{Chemicals}

The anhydrous alkaline chlorides $\mathrm{NaCl}-2 \mathrm{CsCl}$ eutectic $(99.99 \%), \mathrm{NaCl}-\mathrm{KCl}$ eutectic $(99.99 \%), \mathrm{LiCl}-$ $\mathrm{KCl}$ eutectic (99.99\%), $\mathrm{CsCl}(99.99 \%)$ and $\mathrm{EuCl}_{3}$ (99.99\%) were purchased from Aldrich-APL LLC and used without further treatment. All other chemicals were of reagent grade quality.

\subsection{Apparatus}

The spectroelectrochemical cell used for the spectrophotometric and voltammetric studies was described in [11]. The self-registering spectrophotometer JASCO V-350 (JASCO Co.) was used for the measurements over wavenumbers from 15000 to $36000 \mathrm{~cm}^{-1}$. The sample cell was a quartz tube, $35 \mathrm{~cm}$ in length and $13 \mathrm{~mm}$ in inner diameter. To the bottom of the tube a transparent optical measurement cell, having a $10 \mathrm{~mm}$ light path, was welded. In the cyclic voltammetry, a pyro-graphite-coated graphite rod (Tokai Carbon Co.) of $3 \mathrm{~mm}$ diameter was used as working and counter electrode. Instead of the pyro-graphite electrode a molybdenum rod electrode was also tested as working electrode, but it was found that it is not adoptable for repeated use because of elution. A silver|silver ion $\left(\mathrm{Ag} \mid \mathrm{Ag}^{+}\right)$electrode was used as a reference electrode. This electrode consisted of a closed end tube of porous alumina $\left(50 \% \mathrm{Al}_{2} \mathrm{O}_{3}+46 \% \mathrm{SiO}_{2}\right.$; Nikkato Co.) in which alkaline chloride eutectic salt containing $4.85 \mathrm{~mol} \% \mathrm{AgCl}$ was placed, and an $\mathrm{Ag}$ wire of $1 \mathrm{~mm}$ diameter was immersed in the salt. In every experiment, the same salt as the bulk solution was used the reference electrode in order to eliminate the effect of a liquid junction potential. If the electromotive force of the reference electrode was not known, such as in case of $\mathrm{NaCl}-2 \mathrm{CsCl}$, an experiment to calibrate it to the $\mathrm{Cl}_{2} / \mathrm{Cl}^{-}$electrode was carried out.

The temperature of the cell was controlled in the range 723 to $1123 \mathrm{~K}$ by an automatic temperature control system. The electrochemical measurement system Hz-3000 (Hokuto Denko Co. Ltd.) was used for the cyclic voltammetry and controlled potential electrolysis $[11,12]$.

All the experiments were carried out in a glove box filled with dry argon, and the humidity and oxygen impurity was continuously kept below 1 ppm.

\subsection{Determination of the Formal Redox Potential by a Spectroelectrochemical Method}

The formal redox potential of the $\mathrm{Eu}^{2+} / \mathrm{Eu}^{3+}$ couple, $E_{\mathrm{Eu}(\mathrm{II}) / \mathrm{Eu}(\mathrm{III})}^{\mathrm{O}}$, was determined by the relation between the equilibrium potential and the ratio of the concentrations of $\mathrm{Eu}^{2+}$ and $\mathrm{Eu}^{3+}$ in the melt, which was simultaneously monitored with the absorption spectra of $\mathrm{Eu}^{2+}$ and $\mathrm{Eu}^{3+}$. The spectrum of $\mathrm{Eu}^{3+}$ was measured after dissolving a weighted amount of $\mathrm{EuCl}_{3}$ in the melt. The spectrum of $\mathrm{Eu}^{2+}$ was measured after reducing $\mathrm{Eu}^{3+}$ completely to $\mathrm{Eu}^{2+}$ by controlled potential electrolysis. Equilibrium potential measurement at changed ratios of the concentration of $\mathrm{Eu}^{2+}$ and $\mathrm{Eu}^{3+}$ was performed by following procedure. As step (i) europium ions in the melt were completely reduced to $\mathrm{Eu}^{2+}$ by controlled potential electrolysis. As step (ii), after a portion of $\mathrm{Eu}^{2+}$ was oxidized to $\mathrm{Eu}^{3+}$ by controlled potential electrolysis for about $10 \mathrm{~min}$, absorption spectra and equilibrium potentials were measured. Step (ii) was repeated until the oxidation of $\mathrm{Eu}^{2+}$ to $\mathrm{Eu}^{3+}$ was completed. The concentrations of $\mathrm{Eu}^{2+}$ and $\mathrm{Eu}^{3+}$ were monitored as the integral of the absolute band from 27027 to $23810 \mathrm{~cm}^{-1}$. The logarithm of the ratio of the concentrations of $\mathrm{Eu}^{2+}$ to $\mathrm{Eu}^{3+}$ was plotted as a function of the equilibrium potential. Here, the equilibrium potential in the melt was measured as rest potential between the reference and working electrode. The potential at $\ln \left[\mathrm{Eu}^{2+}\right] /\left[\mathrm{Eu}^{3+}\right]=0$ gave the formal redox potential of the $\mathrm{Eu}^{2+} / \mathrm{Eu}^{3+}$ cou- 


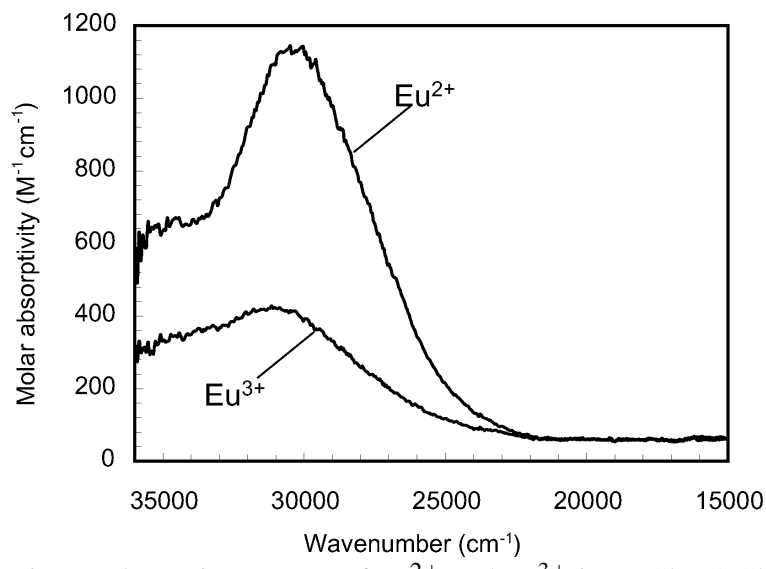

Fig. 1. Absorption spectra of $\mathrm{Eu}^{2+}$ and $\mathrm{Eu}^{3+}$ in $\mathrm{NaCl}-2 \mathrm{CsCl}$ melt at $923 \mathrm{~K}$.

ple. In these experiments, involving electrolysis operation, a counter electrode, having a protective tube, was used. This counter electrode had the same configuration as the reference electrode, so that the counter reaction of the electrolysis occured only in the isolated area.

\section{Results and Discussion}

\subsection{Determination of the Formal Redox Potential of the $E u^{2+} / E u^{3+}$ Couple, $E_{E u(I I) / E u(I I I)}^{\mathrm{O} \prime}$,} in $\mathrm{NaCl}-2 \mathrm{CsCl}$ Melt by Spectroelectrochemistry

The observed absorption spectrum of $8.11 \times 10^{-4} \mathrm{M}$ $\mathrm{EuCl}_{3}$ in the $\mathrm{NaCl}-2 \mathrm{CsCl}$ melt at $923 \mathrm{~K}$ is shown in Figure 1. The molar absorptivity of $\mathrm{Eu}^{3+}$ at the maximum of the charge transfer band, $31200 \mathrm{~cm}^{-1}$, was determined to be $(420 \pm 21) \mathrm{M}^{-1} \mathrm{~cm}^{-1}$. In order to measure the spectrum of $\mathrm{EuCl}_{2}$, controlled potential electrolysis was carried out with $-1.55 \mathrm{~V}$ vs. $\mathrm{Cl}_{2} / \mathrm{Cl}^{-}$for $30 \mathrm{~min}$. The $30 \mathrm{~min}$ electrolysis was found to be sufficient for a quantitative reaction since there was no further growth of the absorption peak of $\mathrm{Eu}^{2+}$ after $30 \mathrm{~min}$, and the equilibrium potential became by $550 \mathrm{mV}$ more negative than the anticipated formal potential. The absorption intensity of $\mathrm{Eu}^{2+}$, which is attributable to the $4 \mathrm{f}^{7} \rightarrow 4 \mathrm{f}^{6} 5 \mathrm{~d}^{1}$ transition [14], was higher than that of $\mathrm{Eu}^{3+}$, and gave the molar absorptivity $(1130 \pm 56) \mathrm{M}^{-1} \mathrm{~cm}^{-1}$ at $30300 \mathrm{~cm}^{-1}$. Similar spectra of $\mathrm{Eu}^{3+}$ and $\mathrm{Eu}^{2+}$ in molten salts have been reported in earlier studies [14-16].

The determination of $E_{\mathrm{Eu}(\mathrm{II}) / \mathrm{Eu}(\mathrm{III})}^{\mathrm{\prime}}$ by a spectroelectrochemical method was carried out by using $\mathrm{NaCl}$ -

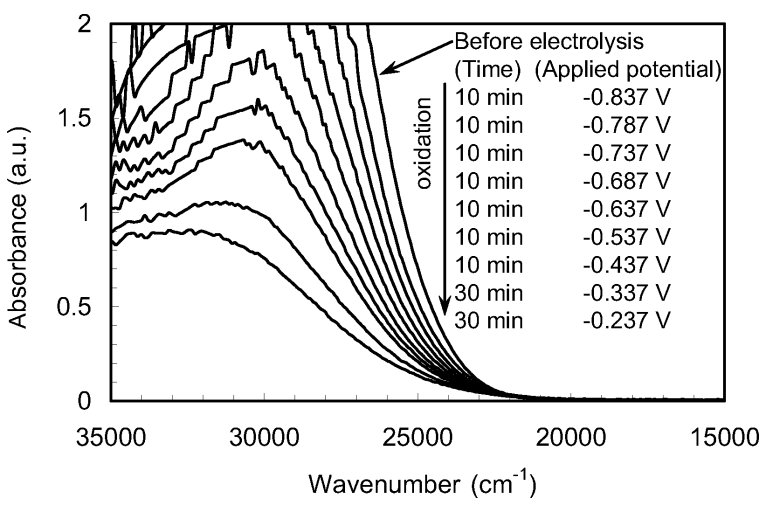

Fig. 2. Absorption spectra of europium ions in molten $\mathrm{NaCl}-$ $2 \mathrm{CsCl}$ at $923 \mathrm{~K}$, while oxidizing $\mathrm{Eu}^{2+}$ to $\mathrm{Eu}^{3+}$.

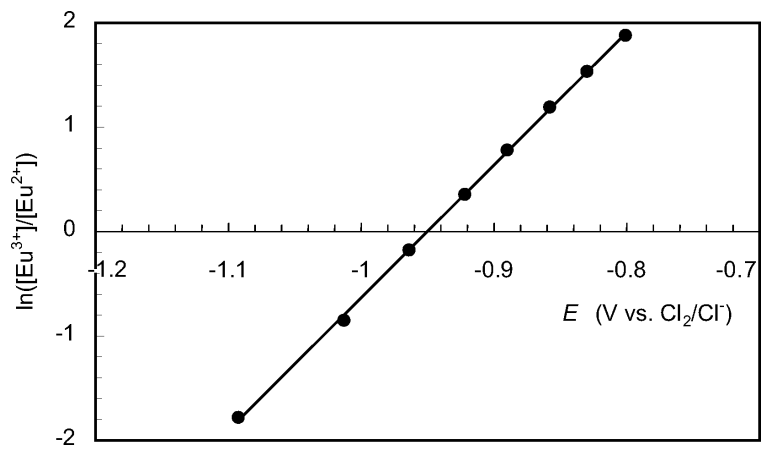

Fig. 3. Relation between the logarithm of the concentration ratio $\mathrm{Eu}^{3+} / \mathrm{Eu}^{2+}$ and the rest potential in molten $\mathrm{NaCl}-2 \mathrm{CsCl}$ at $923 \mathrm{~K}$.

$2 \mathrm{CsCl}$ containing $2.17 \times 10^{-4} \mathrm{M} \mathrm{EuCl}_{2}$. In order to oxidize $\mathrm{Eu}^{2+}$ to $\mathrm{Eu}^{3+}$, potential-controlled electrolysis was performed by applying $-0.85 \mathrm{~V}$ vs. $\mathrm{Cl}_{2} / \mathrm{Cl}^{-}$. As the electrolysis proceeded, the absorption intensity of $\mathrm{Eu}^{2+}$ decreased, the trend of which is shown in Figure 2. After the electrolysis operated for $130 \mathrm{~min}$, no further decrease of the absorption intensity was observed. For evaluating the concentration of $\mathrm{Eu}^{2+}$ and $\mathrm{Eu}^{3+}$, the average absorbance over the region from 27027 to $23810 \mathrm{~cm}^{-1}$ was used. During the progressing electrolysis, the ratio of $\mathrm{Eu}^{2+}$ and $\mathrm{Eu}^{3+}$ was estimated from the decrease of the absorbance from the initial value, corresponding to $100 \% \mathrm{Eu}^{2+}$. Figure 3 shows the relation between the logarithm of the concentration ratio of $\mathrm{Eu}^{2+}$ to $\mathrm{Eu}^{3+}$ and the equilibrium potential. The slope of the straight line was 12.7, and this agreed well with the theoretical value (12.6) of the Nernst equation for one electron transfer at $923 \mathrm{~K}$. The $E_{\mathrm{Eu}}^{\mathrm{O}}$ (II)/Eu(III) was determined to be $(-0.941 \pm 0.004) \mathrm{V}$ vs. $\mathrm{Cl}_{2} / \mathrm{Cl}^{-}$. 


\subsection{Cyclic Voltammetry of Eu in $\mathrm{NaCl}-2 \mathrm{CsCl}$, $\mathrm{NaCl}-\mathrm{KCl}, \mathrm{LiCl}-\mathrm{KCl}$, and $\mathrm{CsCl}$ Melts}

Cyclic voltammograms in $\mathrm{NaCl}-2 \mathrm{CsCl}$ melt containing $0.0696 \mathrm{M}(0.724 \mathrm{wt} \%) \mathrm{EuCl}_{3}$ at $923 \mathrm{~K}$ were measured as shown in Figure 4. The voltammograms were measured at various concentrations of europium ion between $0.0371 \mathrm{M}(0.387 \mathrm{wt} \%)$ and $0.0696 \mathrm{M}$. It was found that the peak currents were proportional to the concentration of the europium ion, and that the mid-point potentials were independent of the concentration of europium ions, as well as on the potential scanning rate, $(-0.940 \pm 0.005) \mathrm{V}$ vs. $\mathrm{Cl}_{2} / \mathrm{Cl}^{-}$. The positive and negative peak currents were proportional to the square root of the potential scanning rate, which indicated that these currents were controlled by the diffusion of the europium ion in the melt. The potential difference between the positive and negative peak potentials at $923 \mathrm{~K}$ was $(0.195 \pm 0.010) \mathrm{V}$, which
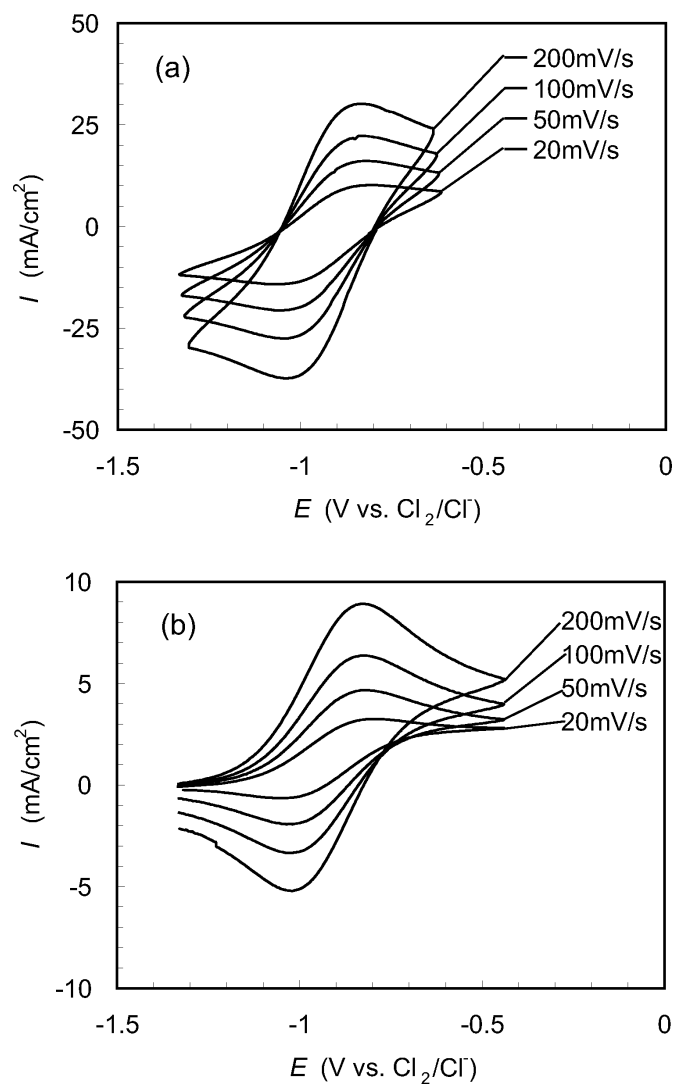

Fig. 4. Cyclic voltammograms of (a) $\mathrm{EuCl}_{3}$ and (b) $\mathrm{EuCl}_{2}$ in molten $\mathrm{NaCl}-\mathrm{CsCl}$ at $923 \mathrm{~K}$. Working electrode: graphite electrode; potential scanning rate: $20,50,100$, and $200 \mathrm{mV}$ $\mathrm{s}^{-1}$, respectively.
Table 1. Comparison of formal redox potentials of the $\mathrm{Eu}^{2+} / \mathrm{Eu}^{3+}$ couple, $E_{\mathrm{Eu}(\mathrm{II}) / \mathrm{Eu}(\mathrm{III})}^{\prime}\left(\mathrm{V}\right.$ vs. $\left.\mathrm{Cl}_{2} / \mathrm{Cl}^{-}\right)$, in $\mathrm{NaCl}-$ $\mathrm{KCl}, \mathrm{NaCl}-2 \mathrm{CsCl}, \mathrm{CsCl}$, and $\mathrm{KCl}$ melts.

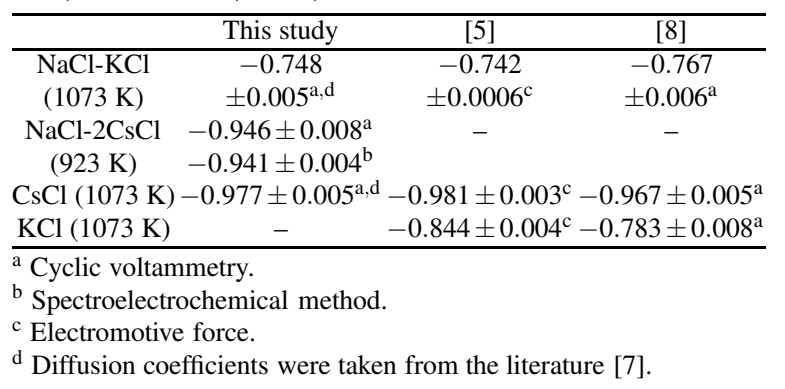

agreed with the fact that the reaction was reversible with one electron transfer. The diffusion coefficient of $\mathrm{Eu}^{3+}$ at $923 \mathrm{~K}$ was calculated from the peak currents to be $2.61 \times 10^{-5} \mathrm{~cm}^{2} \mathrm{~s}^{-1}$. In order to determine the diffusion coefficient of $\mathrm{Eu}^{2+}$, cyclic voltammograms were also recorded for the solution of $\mathrm{Eu}^{2+}$, which was prepared by quantitative electrolytic reduction. The diffusion coefficient of $\mathrm{Eu}^{2+}$ in the molten salt at $923 \mathrm{~K}$ was estimated from the peak currents to be $3.78 \times$ $10^{-5} \mathrm{~cm}^{2} \mathrm{~s}^{-1}$. The mid-point potential was determined to be $(-0.922 \pm 0.005) \mathrm{V}$ vs. $\mathrm{Cl}_{2} / \mathrm{Cl}^{-} \cdot E_{\mathrm{Eu}(\mathrm{II}) / \mathrm{Eu}(\mathrm{III})}^{\mathrm{O}}$ was determined to be $(-0.946 \pm 0.008) \mathrm{V}$ vs. $\mathrm{Cl}_{2} / \mathrm{Cl}^{-}$ by using the above determined diffusion coefficients. $E_{\mathrm{Eu}(\mathrm{II}) / \mathrm{Eu}(\mathrm{III})}$ determined by cyclic voltammetry agreed well with that determined by the spectroelectrochemical method within errors. The effect of the diffusion coefficient term to $E_{\mathrm{Eu}(\mathrm{II}) / \mathrm{Eu}(\mathrm{III})}$ was less than $0.015 \mathrm{~V}$

Generally, the standard potential is determined by cyclic voltammetry, using molybdenum or tungsten as a working electrode, because of their faster kinetics than glassy carbon electrodes. However, in this study the reversibility of $\mathrm{Eu}^{2+} / \mathrm{Eu}^{3+}$ was confirmed to be high even with pyro-graphite carbon electrodes, and this proved the agreement between the spectroelectrochemical measurement and cyclic voltammetry. The advantage of the spectroelectrochemical measurement is that it does not depend on electrochemical dynamics, but is based on the snapshot observation of the equilibrium. In the case of $\mathrm{Eu}$, which has a rather high molar absorptivity, the spectroelectrochemical technique gives a better detection limit.

Table 1 compares our results with the literature $[5,8]$ values in $\mathrm{NaCl}-\mathrm{KCl}$ and $\mathrm{CsCl}$ melts at $1073 \mathrm{~K}$. The literature values in Table 1 for various melt compositions at $1073 \mathrm{~K}$ were calculated from the equations reported by Novoselova et al. [5] and Kuznetsov et 


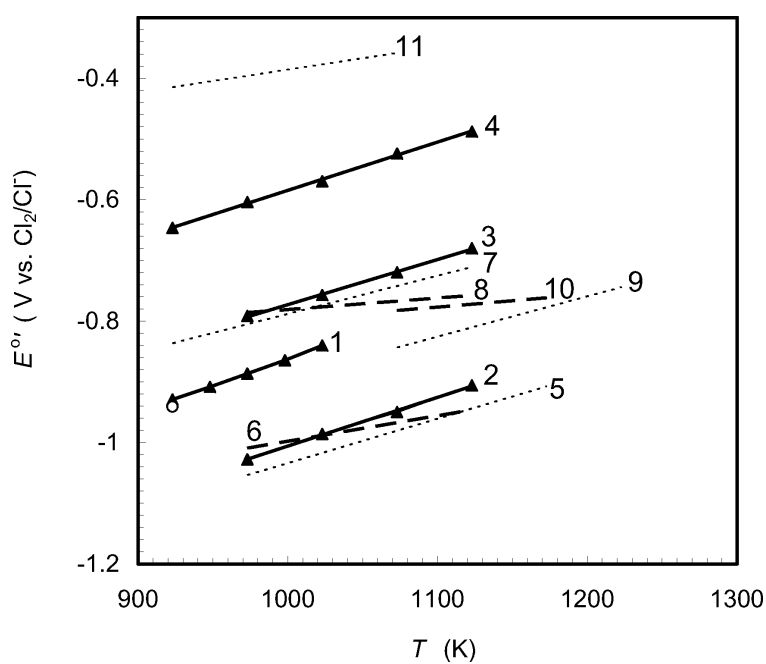

Fig. 5. Relations between the redox potential of the $\mathrm{Eu}^{2+} / \mathrm{Eu}^{3+}$ couple in various molten salts. Lines $1-4$ are the results in $\mathrm{NaCl}-2 \mathrm{CsCl}, \mathrm{CsCl}, \mathrm{NaCl}-\mathrm{KCl}$, and $\mathrm{LiCl}-\mathrm{KCl}$, respectively, determined in this study. Lines 5, 7, 9, and 11 are results in $\mathrm{CsCl}, \mathrm{NaCl}-\mathrm{KCl}, \mathrm{KCl}$, and $\mathrm{LiCl}$, respectively, reported by Novoselova et al. [5], and lines 6, 8, and 10 are results in $\mathrm{CsCl}, \mathrm{NaCl}-\mathrm{KCl}$, and $\mathrm{KCl}$, respectively, reported by Kuznetsov et al. [8]. The closed plots (open circle) are results determined by spectroelectrochemistry. Diffusion coefficients of lines $1-4$ are not taken into consideration.

al. [8]. The difference of the $E_{\mathrm{Eu}(\mathrm{OI}) / \mathrm{Eu}(\mathrm{III})}^{\mathrm{O}}$ values between our study and the literature is 5 to $20 \mathrm{mV}$.

\subsection{Temperature Dependence of the Redox Potential of the $\mathrm{Eu}^{2+} / \mathrm{Eu}^{3+}$ Couple in Various Alkali Chloride Molten Salts}

In order to evaluate the temperature dependence of the redox potential of an Eu couple, cyclic voltammograms were measured in $\mathrm{NaCl}-2 \mathrm{CsCl}, \mathrm{NaCl}-\mathrm{KCl}$, $\mathrm{LiCl}-\mathrm{KCl}$, and $\mathrm{CsCl}$, respectively, at various temperatures between 723 and $1123 \mathrm{~K}$. The variation of the mid-point potential of the anodic and cathodic peak, $E_{\mathrm{Eu}(\mathrm{II}) / \mathrm{Eu}(\mathrm{III})}$, in the $\mathrm{NaCl}-2 \mathrm{CsCl}$ melt along with temperature can be expressed as a function of temperature between 923 and $1023 \mathrm{~K}$ as

$$
\begin{aligned}
& E_{\mathrm{Eu}(\mathrm{II}) / \mathrm{Eu}(\mathrm{III})}=8.862 \times 10^{-4} T-1.748 \\
& \left(\mathrm{~V} \text { vs. } \mathrm{Cl}_{2} / \mathrm{Cl}^{-} \text {in } \mathrm{NaCl}-2 \mathrm{CsCl}, 923 \leq T \leq 1023\right) .
\end{aligned}
$$

This is shown as line 1 in Fig. 5, and agrees well with the dot determined by the spectroelectrochemical method plotted as open circle.

Temperature dependence of $E_{\mathrm{Eu}(\mathrm{II}) / \mathrm{Eu}(\mathrm{III})}$ in $\mathrm{NaCl}$ $\mathrm{KCl}, \mathrm{LiCl}-\mathrm{KCl}$, and $\mathrm{CsCl}$ melts was also determined by cyclic voltammetry, as shown as lines $2-4$ in Figure 5. Similarly to the above-mentioned analyses, $E_{\mathrm{Eu}(\mathrm{II}) / \mathrm{Eu}(\mathrm{III})}$ in $\mathrm{NaCl}-\mathrm{KCl}, \mathrm{LiCl}-\mathrm{KCl}$, and $\mathrm{CsCl}$ were expressed as functions by the following equations:

$$
\begin{aligned}
& E_{\mathrm{Eu}(\mathrm{II}) / \mathrm{Eu}(\mathrm{III})}=7.440 \times 10^{-4} T-1.517 \\
& \left(\mathrm{~V} \text { vs. } \mathrm{Cl}_{2} / \mathrm{Cl}^{-} \text {in } \mathrm{NaCl}-\mathrm{KCl}, 923 \leq T \leq 1123\right), \\
& E_{\mathrm{Eu}(\mathrm{II}) / \mathrm{Eu}(\mathrm{III})}=7.947 \times 10^{-4} T-1.380 \\
& \left(\mathrm{~V} \text { vs. } \mathrm{Cl}_{2} / \mathrm{Cl}^{-} \text {in } \mathrm{LiCl}-\mathrm{KCl}, 723 \leq T \leq 1123\right), \\
& E_{\mathrm{Eu}(\mathrm{II}) / \mathrm{Eu}(\mathrm{III})}=8.032 \times 10^{-4} T-1.809 \\
& \left(\mathrm{~V} \text { vs. } \mathrm{Cl}_{2} / \mathrm{Cl}^{-} \text {in } \mathrm{CsCl}, 923 \leq T \leq 1123\right) .
\end{aligned}
$$

The effect of the temperature on $E_{\mathrm{Eu}(\mathrm{II}) / \mathrm{Eu}(\mathrm{III})}$ in $\mathrm{CsCl}, \mathrm{KCl}$ and $\mathrm{NaCl}-\mathrm{KCl}$ melts was reported by Kuznetsov et al. [8], and that in $\mathrm{LiCl}, \mathrm{NaCl}-\mathrm{KCl}, \mathrm{KCl}$, and $\mathrm{CsCl}$ melts by Novoselova et al. [5]. These reported functions are shown as lines 5-11, respectively, in Figure 5. $E_{\mathrm{Eu}(\mathrm{II}) / \mathrm{Eu}(\mathrm{III})}$ in $\mathrm{NaCl}-\mathrm{KCl}$ determined in this study (line 3) shows good agreement with the lines 7 and 8, reported by Novoselova et al. [5] and Kuznetsov et al. [8]. $E_{\mathrm{Eu}(\mathrm{II}) / \mathrm{Eu}(\mathrm{III})}$ in $\mathrm{CsCl}$, determined in this study (line 2), is close to line 6 [8], whereas it is about $30 \mathrm{mV}$ more positive than line 5 [5]. The slopes of the lines 1-4, which are obtained by the present study, are similar to those of lines 5, 7, 9, 11 reported by Novoselova et al. [5], but they are distinctly different from those of lines 6, 8, 10 reported by Kuznetsov et al. [8]. The difference of these slopes by Kuznetsov et al. could not be explained by us.

\section{Conclusion}

The redox equilibrium of europium ions was studied for molten $\mathrm{NaCl}-2 \mathrm{CsCl}$. The $E^{\mathrm{o} \prime} \mathrm{Eu}(\mathrm{II}) / \mathrm{Eu}(\mathrm{III})$ in $\mathrm{NaCl}$ $2 \mathrm{CsCl}$ at $923 \mathrm{~K}$ was determined to be $(-0.941 \pm$ $0.004) \mathrm{V}$ vs. $\mathrm{Cl}_{2} / \mathrm{Cl}^{-}$by using the spectroelectrochemical method. This value agreed with that determined by cyclic voltammetry, $(-0.946 \pm 0.008) \mathrm{V}$ vs. $\mathrm{Cl}_{2} / \mathrm{Cl}^{-}$. The temperature dependence of $E_{\mathrm{Eu}(\mathrm{II}) / \mathrm{Eu}(\mathrm{III})}$ was investigated for various molten chlorides, which showed the following relations:

$$
\begin{aligned}
& E_{\mathrm{Eu}(\mathrm{II}) / \mathrm{Eu}(\mathrm{III})}=8.862 \times 10^{-4} T-1.748 \\
& \left(\mathrm{~V} \text { vs. } \mathrm{Cl}_{2} / \mathrm{Cl}^{-} \text {in } \mathrm{NaCl}-2 \mathrm{CsCl}, 923 \leq T \leq 1023\right), \\
& E_{\mathrm{Eu}(\mathrm{II}) / \mathrm{Eu}(\mathrm{III})}=7.440 \times 10^{-4} T-1.517 \\
& \left(\mathrm{~V} \text { vs. } \mathrm{Cl}_{2} / \mathrm{Cl}^{-} \text {in } \mathrm{NaCl}-\mathrm{KCl}, 923 \leq T \leq 1123\right),
\end{aligned}
$$


196

$$
\begin{aligned}
& E_{\mathrm{Eu}(\mathrm{II}) / \mathrm{Eu}(\mathrm{III})}=7.947 \times 10^{-4} T-1.380 \\
& \left(\mathrm{~V} \text { vs. } \mathrm{Cl}_{2} / \mathrm{Cl}^{-} \text {in } \mathrm{LiCl}-\mathrm{KCl}, 723 \leq T \leq 1123\right), \\
& E_{\mathrm{Eu}(\mathrm{II}) / \mathrm{Eu}(\mathrm{III})}=8.032 \times 10^{-4} T-1.809 \\
& \left(\mathrm{~V} \text { vs. } \mathrm{Cl}_{2} / \mathrm{Cl}^{-} \text {in } \mathrm{CsCl}, 923 \leq T \leq 1123\right) .
\end{aligned}
$$

$E_{\mathrm{Eu}(\mathrm{II}) / \mathrm{Eu}(\mathrm{III})}$ and its temperature dependence, precisely determined in the present study, can help to understand the coordination change of europium complexes.

[1] S. Vavilov, T. Kobayashi, and M. Myochin, J. Nucl. Sci. Technol. 41, 1018 (2004).

[2] T. Kobayashi, M. Fukushima, and K. Fujii, J. Nucl. Sci. Technol. 42, 861 (2005).

[3] K.E. Johnson and J.R. Mackenzie, J. Electrochem. Soc. 116, 1697 (1969).

[4] B. Gilbert, V. Demarteau, and G. Duyckaerts, J. Electroanal. Chem. 89, 123 (1978).

[5] A. Novoselova, V. Khokhlov, and V. Shishkin, Prog. Molten Salt Chem. 1, 379 (2000).

[6] A. Novoselova, V. Khokhlov, and V. Shishkin, Z. Naturforsch. 56a, 837 (2001).

[7] S. A. Kuznetsov and M. Gaune-Escard, J. Nucl. Sci. Tech. Suppl. 3, 628 (2002).

[8] S. A. Kuznetsov, L. Rycerz, and M. Gaune-Escard, J. Nucl. Mater. 344, 152 (2005).
A. Uehara et al. · Eu Ions in Alkali Chloride Melts

UV/Vis absorption spectra of $\mathrm{Eu}^{3+}$ and $\mathrm{Eu}^{2+}$ were quantitatively prepared by electrolysis in $\mathrm{NaCl}$ $2 \mathrm{CsCl}$ at $923 \mathrm{~K}$, and their spectra were measured. Their molar absorptivities were determined to be $(420 \pm 21) \mathrm{M}^{-1} \mathrm{~cm}^{-1}$ at $31200 \mathrm{~cm}^{-1}$ and $(1130 \pm$ 56) $\mathrm{M}^{-1} \mathrm{~cm}^{-1}$ at $30300 \mathrm{~cm}^{-1}$.

\section{Acknowledgement}

We thank Mr. Roy Jacobus for his help in improving the English expressions of this paper.

[9] A. J. Bard and L. R. Faulkner, Electrochemical Methods, John Wiley \& Sons, New York 2001, Chapter 17.

[10] M. V. Smirnov and A. M. Potapov, Electrochim. Acta 39, 143 (1994).

[11] T. Nagai, T. Fujii, O. Shirai, and H. Yamana, J. Nucl. Sci. Technol. 41, 690 (2004).

[12] T. Nagai, A. Uehara, T. Fujii, O. Shirai, N. Sato, and H. Yamana, J. Nucl. Sci. Technol. 42, 1025 (2005).

[13] C. V. Banks, M. R. Heusinkveld, and J. W. O'Laughlin, Anal. Chem. 33, 1235 (1961).

[14] D. S. McClure and Z. Kiss, J. Chem. Phys. 39, 3251 (1963).

[15] K.E. Johnson, J.R. Mackenzie, and N. Sandoe, J. Chem. Soc. A, 2644 (1968).

[16] W.-J. Gau and I.-W. Sun, J. Electrochem. Soc. 143, 914 (1996). 